\title{
UJI AKTIVITAS ANTIBAKTERI PIGMEN KAROTENOID DARI ISOLAT BAKTERI SIMBION KARANG LUNAK Sarcophyton sp. TERHADAP PERTUMBUHAN BAKTERI Staphylococcus aureus ATCC 25923
}

\author{
Awang Surya Wiguna ${ }^{1}$, Lia Kusmita ${ }^{1}$, Ocky Karna Radjasa ${ }^{2}$ \\ ${ }^{1}$ Sekolah Tinggi Ilmu Farmasi "Yayasan Pharmasi" Semarang, Indonesia \\ ${ }^{2}$ Fakultas Perikanan dan Ilmu Kelautan, UNDIP, Semarang, Indonesia
}

\begin{abstract}
Abstrak
Mikroba penghasil antibiotik dapat berupa fungi maupun bakteri yang bersimbiosis pada organisme lain. Bakteri simbion karang lunak merupakan mikroorganisme penghasil pigmen karotenoid yang dapat berfungsi sebagai antibiotik dengan mekanisme kerja berikatan dengan porin (protein transmembran) membentuk ikatan polimer yang kuat sehingga mengakibatkan rusaknya porin. Bakteri dapat menyebabkan infeksi apabila imunitas seseorang mulai menurun dan melakukan replikasi dalam jumlah abnormal seperti Eschericia coli dan Staphylococcus aureus. Penyakit infeksi yang disebabkan oleh bakteri Staphylococcus aureus dalam keadaan abnormal diantaranya adalah infeksi folikel (akar) rambut dan kelenjar keringat, bisul, infeksi pada luka, meningitis, serta pneumonia. Pigmen karotenoid yang dihasilkan dari bakteri simbion mampu menghambat Eschericia coli dengan zona hambat sebesar $11,36 \mathrm{~mm}$. Tujuan penelitian ini untuk mengetahui aktivitas antibakteri ekstrak pigmen karotenoid dari bakteri simbion karang lunak Sarcophyton sp. terhadap pertumbuhan bakteri Staphylococcus aureus ATCC 25923 pada konsentrasi 0,5\% b/v, 0,75\% b/v, dan $1 \% \mathrm{~b} / \mathrm{v}$ dengan metode difusi agar dengan teknik perforasi. Bakteri yang menghasilkan pigmen karotenoid dibiakkan dan diidentifikasi dengan mengisolasi DNA untuk dilakukan PCR dan mensequen hasilnya. Identifikasi pigmen dilakukan dengan menggunakan spektrofotometer visible dengan rentang $350-800 \mathrm{~nm}$. Hasil identifikasi pigmen menunjukkan bahwa pigmen yang dihasilkan oleh bakteri simbion dari karang lunak Sarcophyton sp adalah karotenoid yaitu pada rentang 300-600 nm. Hasil penelitian menunjukkan aktivitas antibakteri dengan rata - rata diameter zona hambat pada konsentrasi $0,5 \%$ b/v sebesar $6,78 \mathrm{~mm}$, konsentrasi $0,75 \% \mathrm{~b} / \mathrm{v}$ sebesar $9,78 \mathrm{~mm}$, konsentrasi $1 \% \mathrm{~b} / \mathrm{v}$ sebesar 14,16 $\mathrm{mm}$ serta diameter zona hambat kontrol pembanding amoksisilin trihidrat sebesar $18,75 \mathrm{~mm}$.
\end{abstract}

Kata kunci: Antibakteri, karotenoid, Sarcophyton sp., simbion, Staphylococcus aureus 


\section{Pendahuluan}

Indonesia merupakan negara tropis yang tidak luput dari ancaman penyakit infeksi. Kondisi wilayah yang bersuhu panas, lembab, dan basah mengakibatkan pertumbuhan mikroba penyebab infeksi semakin pesat. Infeksi disebabkan oleh bakteri seperti Staphylococcus aureus pada keadaan abnormal yang dapat mengakibatkan, infeksi folikel (akar) rambut dan kelenjar keringat, bisul, infeksi pada luka, meningitis, serta pneumonia. ${ }^{1}$ Penyakit infeksi dapat diobati dengan menggunakan antibiotik. Sumber penghasil antibiotik bisa berasal dari mikroba laut. Mikroba penghasil antibiotik dapat berupa fungi maupun bakteri yang biasanya bersimbiosis pada organisme lain. ${ }^{2}$ Mikroba laut menghasilkan senyawa bioaktif yang sama dengan inangnya seperti terpenoid, alkaloid, flavonoid, dan steroid. ${ }^{3}$

Karotenoid merupakan salah satu jenis pigmen yang berpotensi untuk dikembangkan sebagai antibakteri. Pigmen karotenoid dari bakteri yang berasosiasi dengan karang lunak Halimeda $s p$. memiliki senyawa antibakteri terhadap bakteri Staphylococcus aureus dengan mekanisme kerja berikatan dengan porin (protein transmembran) membentuk ikatan polimer yang kuat sehingga mengakibatkan rusaknya porin dari bakteri Staphylococcus aureus yang merupakan jalan masuknya nutrisi. Berdasarkan uraian di atas, dilakukan penelitian lebih lanjut tentang pigmen karotenoid dari bakteri simbion karang lunak Sarcophyton $s p$. yang dapat berpotensi sebagai antibakteri terhadap bakteri Staphylococcus aureus. ${ }^{3}$

\section{Metode}

Alat yang digunakan dalam penelitian ini adalah Alat selam, cool box Marlina, gunting karang, kertas label, kantung plastik, otoklaf E-Scientific , cawan petri Pyrex, jarum ose Herma, lampu spiritus Herma, Laminar Air Flow Hyang, lumpang dan alu, mikropipet beserta tipnya, neraca analitik KERN, tabung reaksi Pyrex, tabung ependrof, alat elektroforesis, mesin DNA thermal cycler Kyratec, centrifuge Nesco 80-2, tabung centrifuge Pyrex, kertas saring, pipet tetes Herma, tabung reaksi Pyrex, spektrofotometer UV- Vis Shimadzu - 1240, kuvet Shimadzu, dan tissue lensa. Bahan yang digunakan dalam penelitian ini adalah Ekstrak Pigmen karotenoid dari bakteri simbion karang lunak Sarcophyton sp., media Zobell 2216E Oxoid, air laut steril, aquabidest, chelex, saponin, Phosphat Buffer Saline (PBS), Primer universal 27F (5'AGAGTTTGATCMTGGCTCAG-3') dan primer spesifik eubacteria (5'TACGGYTACCTTGTTACGACTT-3'), GoTaq Green Master Mix, serbuk agarose, etidium bromide, buffer TAE 1 $\mathrm{x}$, loading dye, metanol, gas $\mathrm{N} 2$, bakteri Staphylococcus aureus ATCC 25923, media Nutrient Agar Oxoid, Nutrient Broth Oxoid, Manitol Salt Agar Oxoid, Larutan 0,5 Mc Farland, aquadest steril, Dimetyl Sulphoxide, dan amoksisilin trihidrat.

Pengambilan sampel karang lunak Sarcophyton $s p$. dilakukan di perairan Pulau Cemara Besar, Karimunjawa dengan teknik snorkeling pada kedalaman 2 meter. Sampel disimpan dalam cool box agar tetap segar dan tidak rusak. Waktu pengambilan sampel yaitu pada tanggal 18 Maret 2015.

Isolasi bakteri dilakukan dengan metoda sebaran. Sampel karang lunak Sarcophyton sp. yang diperoleh dari laut dipotong dengan pisau yang disterilkan terlebih dahulu dengan cara swab menggunakan alkohol kemudian dihaluskan menggunakan lumpang dan alu yang disterilkan terlebih dulu dengan cara dibakar dengan spiritus . Sebanyak $1 \mathrm{~g}$ sampel dimasukkan ke dalam tabung reaksi yang berisi $9 \mathrm{ml}$ air laut steril, diperoleh seri pengenceran $10-^{1}$. Seri pengenceran dilakukan sampai diperoleh seri pengenceran $10-^{2}, 10-^{3}, 10-^{4}$ dan $10-^{5}$. Selanjutnya diambil $35 \mu$ d dari masing masing hasil pengenceran suspensi sampel kemudian media agar Zobell 2216E sebanyak $20 \mathrm{ml}$ dituangkan ke dalam cawan 
petri steril dan diinkubasikan pada suhu $37^{\circ} \mathrm{C}$ selama 2 hari. Koloni bakteri berwarna dipisahkan dengan teknik goresan sehingga diperoleh isolat bakteri tunggal berwarna yang berasosiasi dengan invertebrata. Pengamatan koloni bakteri yang dilakukan meliputi pengamatan warna, bentuk dan tektur koloninya dan dipindahkan ke medium yang baru. Selanjutnya cawan petri tersebut diinkubasi pada suhu $37^{\circ} \mathrm{C}$ selama 3 x 24 jam kemudian diamati pertumbuhannya.

Identifikasi secara molekuler dilakukan dengan menggunakan Polimerase Chain Reaction (PCR) 16S rDNA. Primer yang digunakan untuk PCR 16S rDNA adalah primer universal untuk bakteri $27 \mathrm{~F}$ (5'-AGAGTTTGATCMTGGCTCAG-3') dan primer spesifik eubacteria 1492R (5'TACGGYTACCTTGTTACGACTT-3'). Amplifikasi DNA dilakukan dengan pengkondisian alat DNA thermal cycle pada suhu $96^{\circ} \mathrm{C}$ selama 2 menit, selanjutnya sebanyak 25 siklus dengan ketentuan denaturasi pada suhu $96^{\circ} \mathrm{C}$ selama 10 detik; annealing pada suhu $50^{\circ} \mathrm{C}$ selama 5 detik; dan reaksi pemanjangan pada suhu $60^{\circ} \mathrm{C}$ selama 4 menit. Visualisasi hasil amplifikasi DNA dilakukan melalui elektroforesis gel agarose. Pita DNA hasil amplifikasi dilihat dengan menggunakan alat UV transluminator. Analisis sekuen DNA isolat bakteri terbaik kemudian dibandingkan dengan sekuen DNA pada basis data pada situs NCBI. Penelusuran dilakukan menggunakan internet melalui program pelacakan database Basic Local Alignment Search Tool (BLAST).

Pigmen karotenoid diekstrak dari bakteri Pseudoalteromonas rubra yang merupakan bakteri simbion dari karang lunak
Sarcophyton sp. Ekstraksi dilakukan dengan menggunakan metanol dingin Ekstrak pigmen yang didapatkan dikeringkan menggunakan gas nitrogen sehingga didapatkan ekstrak kering. Ekstrak yang didapat dilarutkan dalam pelarut DMSO dan dibuat dalam konsentrasi $0,5 \% \mathrm{~b} / \mathrm{v}$, $0,75 \% \mathrm{~b} / \mathrm{v}$, dan $1 \% \mathrm{~b} / \mathrm{v}$ untuk dilakukan uji aktifitas antibakteri. Uji aktivitas antibakteri dilakukan terhadap bakteri Staphylococcus aureus dengan metode difusi agar dengan teknik perforasi. Amoksisilin trihidrat $0,05 \% \mathrm{~b} / \mathrm{v}$ digunakan sebagai kontrol pembanding. Media yang mengandung suspensi bakteri uji dan ekstrak pigmen karotenoid bakteri simbion diinkubasi pada suhu $37^{\circ} \mathrm{C}$ selama $1 \times 24$ jam. Zona hambat di sekitar sumuran mengindikasikan bahwa ekstrak pigmen karotenoid isolat bakteri simbion mampu menghambat pertumbuhan bakteri uji.

\section{Hasil}

Hasil isolasi diperoleh 5 jenis koloni bakteri simbion yang berbeda, salah satunya berwarna orange yang mengindikasikan pigmen karotenoid dengan kode isolat CBSCP 23. Koloni bakteri tersebut kemudian dimurnikan hingga didapatkan koloni tunggal yang disajikan pada Tabel 1 dan Gambar 1.

Berdasarkan hasil amplifikasi 16S rDNA menunjukkan bahwa isolat bakteri simbion CBSCP 23 menghasilkan pita basa 1500 bp dibandingkan dengan marker DNA. Ukuran pita basa sekitar 1500 - 1600 bp merupakan ukuran dari sekuen 16S rDNA bakteri.4 Hasil visualisasi elektroforesis DNA dapat dilihat pada Gambar 2.

Tabel 1. Hasil Isolasi Bakteri Simbion Karang Lunak Sarcophyton sp.

\begin{tabular}{ccccc}
\hline No & Kode Isolat & Warna & Bentuk & Tekstur \\
\hline 1 & CBSCP 21 & Putih & Bulat & Halus \\
2 & CBSCP 22 & Kuning & Tak Beraturan & Kasar \\
\hline 3 & CBSCP 23 & Orange & Bulat & Halus \\
\hline 4 & CBSCP 24 & Orange tua & Bulat & Kasar \\
5 & CBSCP 25 & Putih & Bulat & Halus \\
\hline
\end{tabular}






Gambar 1. Hasil Purifikasi Bakteri Simbion CBSCP 23

Analisis menggunakan BLAST diperoleh hasil isolat bakteri simbion CBSCP 23 memiliki kemiripan dengan bakteri spesies Pseudoalteromonas rubra dengan homologi sekuen sebesar $98 \%$. Hasil disajikan pada Tabel 2. Isolat yang mempunyai homologi sekuen 16S rDNA antara $93 \%-97 \%$ dapat mewakili identifikasi pada tingkat genus tetapi berbeda pada tingkat spesiesnya, sedangkan

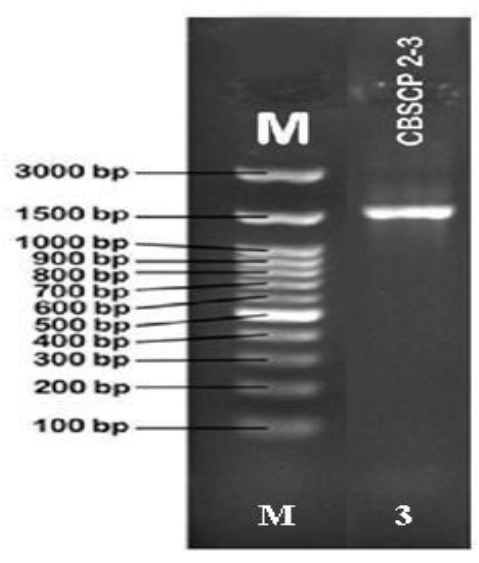

Gambar 2. Visualisasi Hasil Amplifikasi : (M) Marker, (3) DNA Bakteri Simbion CBSCP 23

persamaan sekuen lebih dari $97 \%$ dapat mewakili spesies yang sama. ${ }^{5}$

Hasil analisis pohon filogenetik dari strain bakteri simbion CBSCP 23 menggunakan software MEGA version 5.05 (Molecular Evolutionary Genetics Analysis) disajikan pada Gambar 3. Hasil analisis menunjukkan bahwa isolat bakteri simbion CBSCP 23 memiliki hubungan kekerabatan dengan bakteri Pseudoalteromonas rubra.

Tabel 2. Hasil Penulusuran Homologi BLAST Bakteri Simbion CBSCP 23

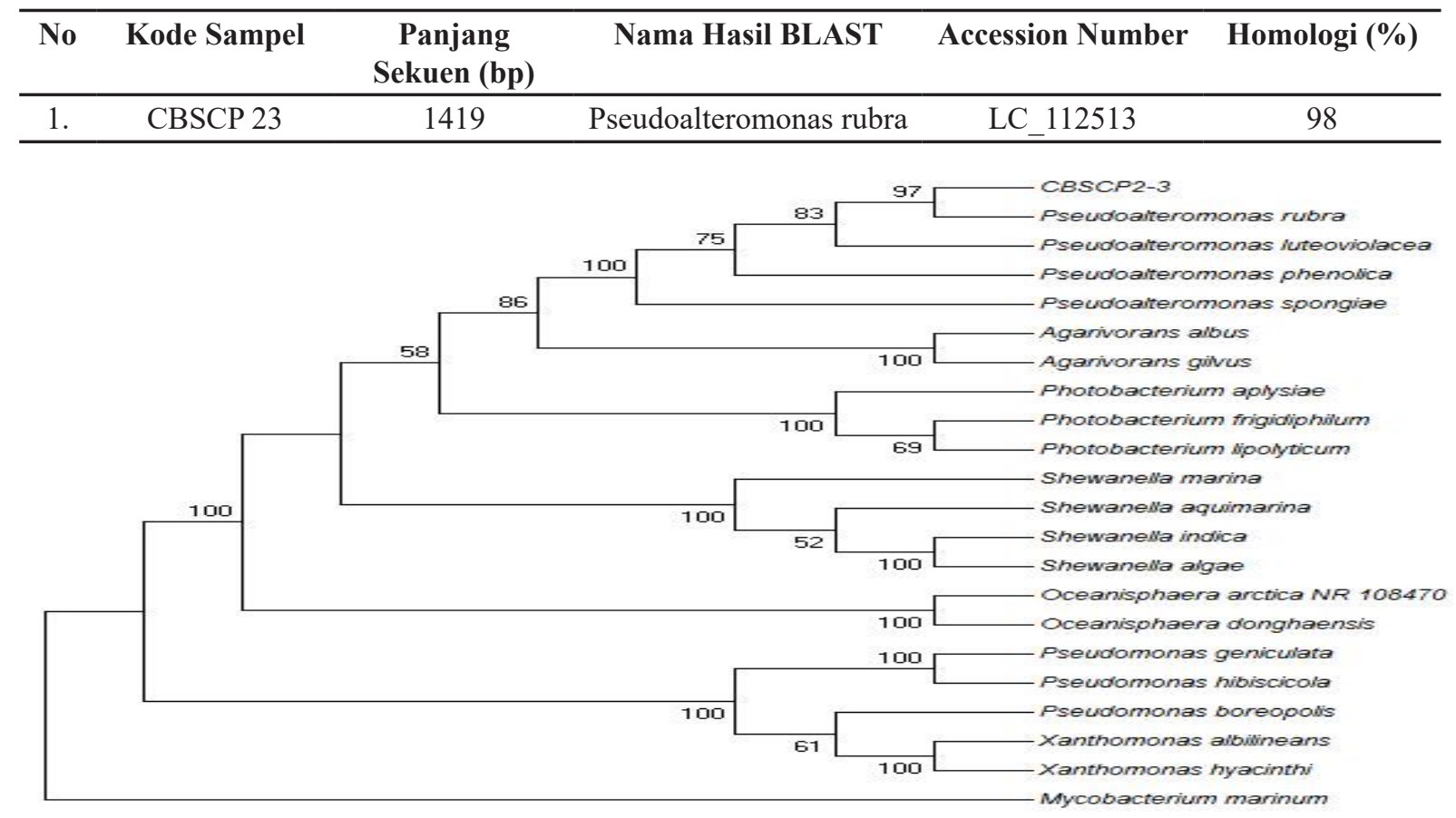

Gambar 3. Pohon Filogenetik Bakteri Simbion CBSCP 23 
Bakteri Pseudoalteromonas rubra merupakan bakteri Gram negatif. ${ }^{6}$ Bakteri Pseudoalteromonas rubra merupakan bakteri aerob berbentuk batang lurus atau sedikit melengkung dengan ukuran $0,2-1,5 \mu \mathrm{m} \times 1,8-4,0 \mu \mathrm{m} .^{7}$ Bakteri Pseudoalteromonas rubra ditemukan pada perairan laut dan melekat pada permukaan batu, ganggang, terumbu karang, binatang laut, sedimen laut, dan juga dijumpai pada perairan pantai. ${ }^{6}$

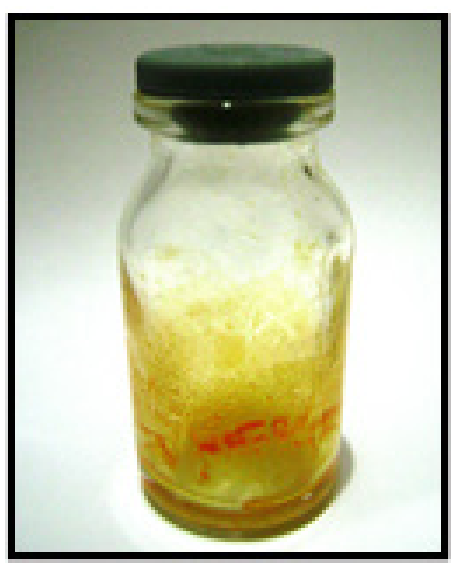

(1)

\section{Pembahasan}

Dari berat basah sel bakteri simbion CBSCP 23 sebanyak 2,8820 g didapatkan ekstrak pigmen kering sebanyak 0,1560 g. Hasil rendemen yang diperoleh adalah $5,41 \%$. Selanjutnya ekstrak kering pigmen dibuat dalam konsentrasi $0,5 \% \mathrm{~b} / \mathrm{v}, 0,75$ $\% \mathrm{~b} / \mathrm{v}$, dan $1 \% \mathrm{~b} / \mathrm{v}$ untuk uji aktivitas antibakteri. Hasil ekstraksi pigmen dapat dilihat pada Gambar 4.

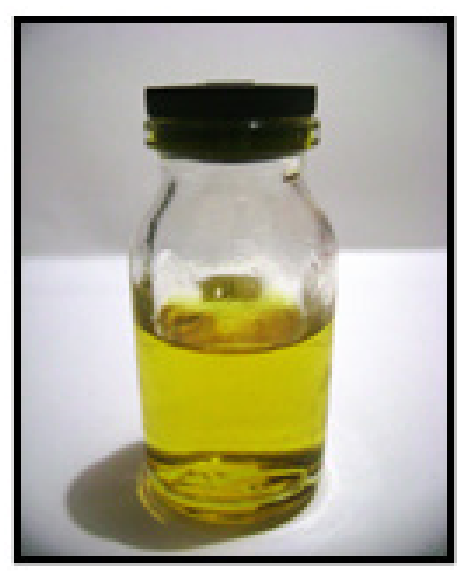

(2)

Gambar 4. Hasil Ekstraksi Pigmen Karotenoid Bakteri Simbion CBSCP 23, (1) Pigmen Kering (2) Larutan Pigmen

Hasil pengukuran pola pigmen yang diperoleh masuk pada rentang $300-600$ nm. Pigmen karotenoid memiliki serapan disekitar $300-600 \mathrm{~nm}$ yaitu didaerah merah. ${ }^{8}$ Berdasarkan hasil pola spektra yang diperoleh dapat dikatakan bahwa pigmen yang terkandung dalam bakteri simbion CBSCP 23 merupakan pigmen karotenoid. Dengan pola spektra yang disajikan pada Gambar 5.

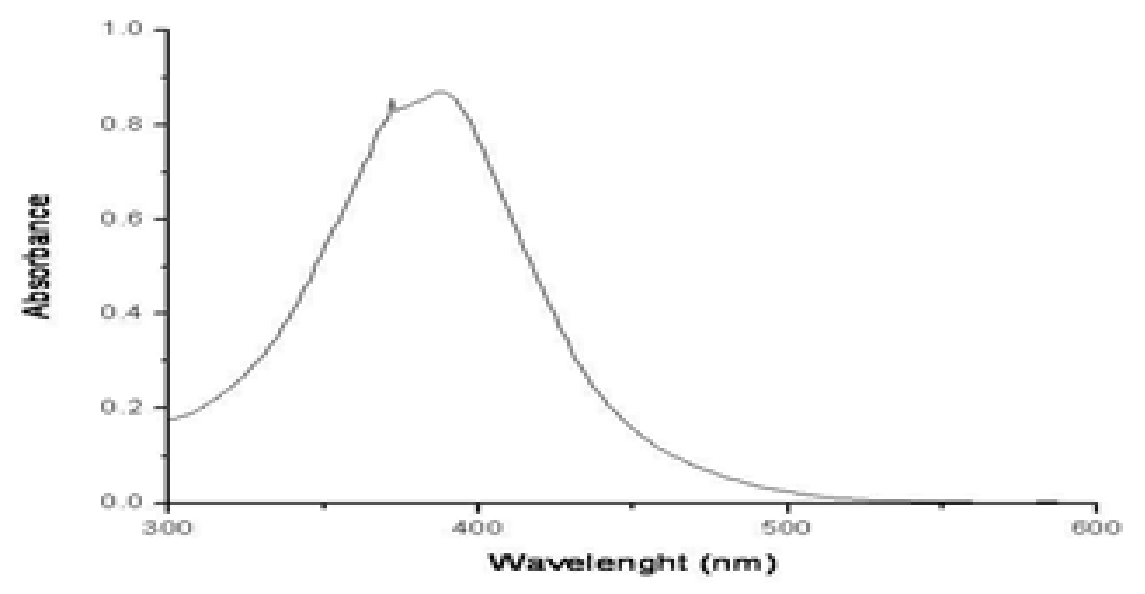

Gambar 5. Pola Spektra Pigmen Karotenoid Bakteri Simbion CBSCP 23 
Hasil pengujian aktivitas antibakteri didapatkan semakin tinggi konsentrasi ekstrak pigmen karotenoid maka aktivitas antibakterinya semakin besar. Mekanisme karotenoid sebagai antibakteri adalah bereaksi dengan porin (protein transmembran) pada membran luar dinding sel bakteri, membentuk ikatan polimer yang kuat sehingga mengakibatkan rusaknya porin. Rusaknya porin yang merupakan pintu keluar masuknya senyawa akan mengurangi permeabilitas dinding sel bakteri yang akan menyebabkan sel bakteri akan kekurangan nutrisi, sehingga pertumbuhan bakteri terhambat. ${ }^{9}$ Data pengukuran aktivitas antibakteri disajikan pada Tabel 3 dan Gambar 6.
Kontrol negatif DMSO tidak memberikan aktivitas antibakteri sehingga diameter zona bening yang dihasilkan terbukti dikarenakan adanya senyawa ekstrak pigmen karotenoid dari bakteri simbion CBSCP 23 yang berdifusi untuk melisis sel bakteri yang terdapat pada permukaan media uji. Kontrol pembanding yang digunakan adalah amoksisilin trihidrat dengan mekanisme kerja merusak fungsi dinding sel bakteri. Amoksisilin mempunyai rumus cincin $\beta$-laktam sehingga dapat mempengaruhi kerja enzim dalam membentuk peptidoglikan yang merupakan komponen pembentuk dinding sel bakteri sehingga mengakibatkan sintesis dinding sel terganggu dan menyebabkan sel lisis. ${ }^{10}$

Tabel 3. Hasil Uji Aktivitas Antibakteri Ekstrak Pigmen Karotenoid Bakteri Simbion CBSCP 23

\begin{tabular}{cccccc}
\hline \multirow{3}{*}{ Replikasi } & \multicolumn{5}{c}{ Diameter Zona Hambat (mm) } \\
\cline { 2 - 6 } & \multicolumn{2}{c}{ Pigmen Karotenoid CBSCP 23 (\%b/v) } & \multicolumn{3}{c}{ Kontrol } \\
\cline { 2 - 6 } & $\mathbf{0 , 5}$ & $\mathbf{0 , 7 5}$ & $\mathbf{1}$ & Positif & Negatif \\
\hline 1 & 7,14 & 9,73 & 15,32 & 19,99 & 0,00 \\
2 & 8,02 & 10,56 & 14,33 & 19,12 & 0,00 \\
3 & 6,58 & 10,79 & 13,45 & 17,94 & 0,00 \\
4 & 6,22 & 8,61 & 13,84 & 17,69 & 0,00 \\
5 & 5,96 & 9,23 & 13,84 & 19,00 & 0,00 \\
Rata - rata & 6,78 & 0,978 & 14,16 & 18,75 & 0,00 \\
\hline
\end{tabular}

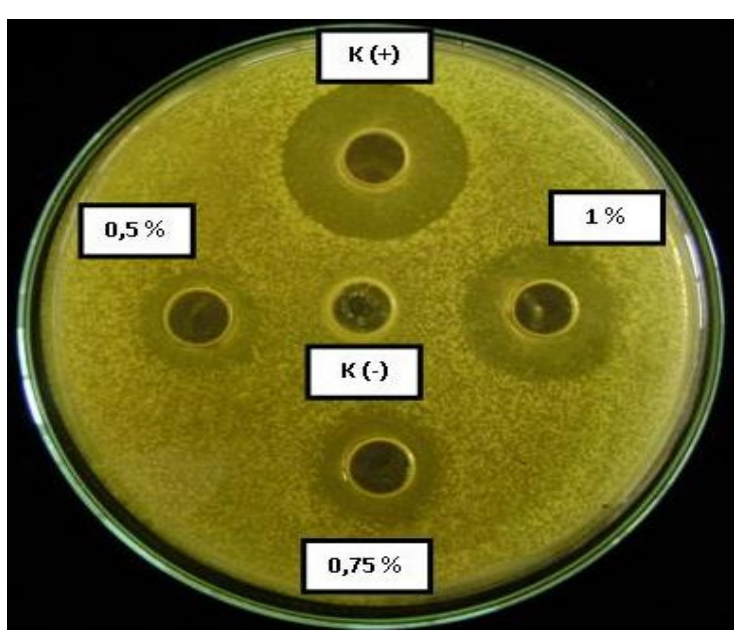

Keterangan :

$0,5 \quad$ : Konsentrasi pigmen karotenoid $0,5 \% \mathrm{~b} / \mathrm{v}$

0,75 : Konsentrasi pigmen karotenoid $0,75 \% \mathrm{~b} / \mathrm{v}$

1 : Konsentrasi pigmen karotenoid $1 \% \mathrm{~b} / \mathrm{v}$

$\mathrm{K}(+) \quad$ : Amoksisilin trihidrat $0,05 \% \mathrm{~b} / \mathrm{v}$

$\mathrm{K}(-) \quad$ : DMSO

Gambar 6. Diameter Hambat Pigmen Karotenoid Bakteri Simbion CBSCP 23 


\section{Simpulan}

Dari hasil penelitian ini diperoleh simpulan bahwa ekstrak pigmen karotenoid bakteri simbion karang lunak Sarcophyton $s p$. dengan kode isolat CBSCP 23 memiliki aktivitas antibakteri terhadap bakteri Staphylococcus aureus ATCC 25923. Adanya perbedaan konsentrasi ekstrakuji yang menghasilkan diameter hambat yang berbeda dalam hal ini semakin meningkat konsentrasi ekstrak uji yang digunakan menghasilkan kenaikan diameter hambat yang terbentuk, menunjukkan adanya aktivitas antibakteri.

\section{Daftar Pustaka}

1. Entjang. 2003. Mikrobiologi dan Parasitologi Untuk Akademi Perawat dan Sekolah Tenaga Kesehatan yang Sederajat. Bandung : PT. Citra Aditia Bakti.

2. Faulkner, D.J. 2000. Highlights of Marine Natural Products Chemistry. J. Nat Prod. Rep., 17 : 1-6.

3. Radjasa, O.K., L. Limantara and A. Sabdono. 2009. Antibacterial activity of a pigment producing-bacterium associated with Halimeda sp. From land-locked marine lake Kakaban, Indonesia. J. Coast. Dev. Vol $12: 100$ $-104$.

4. Sabdono, A. 2006. Biodegradation of chloropyrifos by a marine bacterium Bacilus firmus strain BY6 associated with branching coral Acropora sp. J.Coast. Dev. $10: 115$ - 123

5. Hangstrom, A., J. Pihassi and U.L. Zweifel. 2000. Biogeographical Diversity Among Marone Bacterioplankton. Aquat. Microbiol. Ecol. $21: 231-244$.

6. Gauithier M.J. 1995. Alteromonas rubra sp. nov., a New Marine AntibioticProducing Bacterium. Int. J. Syst. Bacteriol. Oct 1976, p . 459 - 466

7. Dworkin,M., Falkow S., Rosenberg E., Schleifer K.H., and Stackebrandt E. 2006. The Prokaryotes A Handbook on The Biology of Bacteria Thirth Edition Volume 6. Singapore : Springer

8. Gross, J. 1991. Pigments in vegetables. Chlorophylls and carotenoids. An avi Book. Van Nostrand Reinhold. New York.

9. Cowan, M. 1999. Plant Product as Antimicrobial Agent, Clinical Microbiology Review : 12 (4), hal. 564 -582 .

10. Jawetz, Melnick, and Alberg. 2005. Mikrobiologi Kedokteran. Diterjemahkan oleh Nugroho, E. Edisi 20. Jakarta : Buku Kedokteran EGC. 